\title{
RESEARCH ON THE VARIATION OF LIGHT INTENSITY ACROSS SURFACES WITH BEECH SEEDLINGS PLANTED AFTER THE APPLICATION OF THE PROGRESSIVE FELLING TREATMENT
}

\author{
Ilie COVRIG ${ }^{1}$, Mădălina Florina PRESECAN ${ }^{2}$
}

Keywords: light intensity, solar radiation absorption, cut block, lux meters, progressive treatment.

\begin{abstract}
The research we have undertaken seeks to clarify some aspects concerning the specific characteristics of aforest microclimate. Spot measurements were carried out for 12 hours/day, on certain days that are typical for the period of vegetation and, respectively, for the period of vegetative rest. Measurements regarding the intensity of light were conducted across surfaces where progressive felling had been applied. The research findings about the light regime are presented below: 1. Surfaces subjected to the progressive felling treatment I - seeding fellings that create cut block sites in the mature stand canopy u. a. 74 B, UP III, Nirajul Mic, the Sovata Forestry. In these regeneration areas appear noticeable changes of the light regime, caused by the intensity of the fellings, the size of the cut block sites and the position of each cut block site sector. Thus, in clear cut block sites, having an elliptical shape of $0.5 \mathrm{H}^{3} \mathrm{X} 0.75 \mathrm{H}^{*}$, in which seedlings have not yet been planted, the amount of light that reaches the soil surface, in relation to the open field solar radiation, is approx. $1 / 4-1 / 3$ in the eastern and southern sectors, $2 / 3$ in the central sector and, respectively, $2 / 5$ - $1 / 2$ in the western and northern sectors. In the case of elliptical cut block sites, with diagonals of $1.0 \mathrm{H} \mathrm{X} 1.5 \mathrm{H}$, we have found some variations, in the sense that the eastern and the southern sectors receive, at ground surface, approx. $1 / 5-2 / 5$ of the light from an unforested area, the central sector receives a little over $2 / 3$, while the western and the northern sectors
\end{abstract}

\footnotetext{
${ }^{1}$ Associate Professor University of Agricultural Sciences and Veterinary Medicine,Cluj-Napoca, Romania, ilie_covrig@yahoo.com;

${ }^{2} \mathrm{PhD}$. Eng. Transilvania University of Brașov, madalina_presecan@yahoo.com.
} 
receive $4 / 5-1 / 1$ of the light from an unforested area, which is also the area with relatively maximum light availability. 2. Surfaces subjected to the progressive felling treatment II - fellings for expandingcut block sites UP VI, Valea Soveții, u.a 127, the Sovata Forestry. Thus, in an elliptical cut block site (1.0 H X 1.5 H) from UP VI, u.a. 127, at1 p.m., when the sky was overcast, $50 \%$ of full light reached the eastern sector, $40 \%$ reached the southern sector, approx. $80-90 \%$ reached the center of the cut block site, and $75-85 \%$ of the amount of light from an unforested area reached the western and the northern sectors at soil surface level. Forest ecosystems are characterized by a great capacity of solar radiation absorption. As a result of selective processes of absorption, reflection and transmission, carried out at the level of the "active surface", the light regime inside the forest presents a series of distinct features. Light intensity decreases from the top of the canopy to the ground. The decrease is accentuated in the canopy and much slower in the space underneath the canopy, all the way to the ground. Thus, while an average of $66-67 \%$ is recorded at the level of the canopy (2/3 of full light), underneath the canopy it reaches $9 \%$ (under $1 / 10$ of full light) and only $6-7 \%$ of the light from an unforested area is recorded at ground level. Differences are found from one measurement point to another, within the same level, as a result of the foliage structure and the different thickness of the foliage mass located above the measurement point.

\section{Introduction}

From the moment the massive stand stage is completed and the forest ecosystem takes over the functions of an "active surface"(these functions being fulfilled, in an unforested area, by the soil), this role is carried out through the foliage of trees, shrubs and grasses, via the external, above-ground surface of the other plant organs (Mark, M. 1983). Forest ecosystems are characterized by a great capacity of solar radiation absorption. As a result of selective processes of absorption, reflection and transmission, carried out at the level of the "active surface", the light regime insidea forest presents a series of distinct features. The vertical distribution of brightness in a forest depends on several factors, including the intensity of light in the free atmosphere, the position of the sun above the horizon, the mass of the foliage located above the measurement point, and so on.

\section{Research material and method}

The research was conducted in the Sovata Forestry, located in the upper Basin of the Niraj and of the Small Tărnava. In the Sovata Forestry, from the Forestry Department of Mureş County, there are many areas where regeneration 
fellings have been undertaken Regeneration is more or less certain to occur in these areas, after abundant and repeated fruit production. Moreover, following the events of May 1989, when trees were broken down by the snow, and those of November 1995, when trees were downed by the wind, the consistency of a series of tree stands was decreased by two units on average, creating favorable conditions for the production of fruits and the installation of seedlings.

The research was conducted in areas considered as being representative and it essentially aimed to capture the influence of the micro-climate created in the stands of beech, as a result of the application of certain silviculture works, on the process of natural regeneration. Based on the findings, appropriate measures were taken and recommendations were issued for ensuring the best conditions for the natural regeneration of the beech forests from the upper basin of the Niraj and of the Small Târnava rivers, while also advancing the knowledge of the regeneration process of beech forests in general. In organizing and conducting the field research, we focused on the areas in which seedlings had been installed following the abundant fructification of 1994, as well as of the previous years, or whose installation was underway (1999 was another year with abundant fructification).Observations and measurements were made on surfaces where progressive fellings had been conducted (in cut block sites), with the following sub-versions:

- cut block sites with a diameter of $0.5 \mathrm{~h} * \square$

- cut block sites with a diameter of $0.5 \times 1 \mathrm{~h}^{*}$

- cut block sites with a diameter of $1 \times 2 \mathrm{~h} *$

In this version,we also examined the cut block sites created in the stands by the wind fellings from November 1995, as well as areas where no intervention had been made (control block), but where the regeneration had been triggered. The micro-climatic research we carried out aimed tossed light on some aspects concerning the specific character of forest micro-climate. Spot measurements of the light intensity were carried out for 12 hours/ day, on certain days that are typical for the period of vegetation and, respectively, for the period of vegetative rest.

To establish the values of the light intensity in the researched areas, lux meters with a 0-100,000 Lux range were used.

The measurements were performed at the soil level $(-5 \mathrm{~cm})$, at a height equal to that of the natural seedlings (above the canopy) and at $200 \mathrm{~cm}$ from the ground, where the aim was to determine the value of the luminous intensity at this level too. Moreover, in the case of the seedlings installed before 1994 (a year with abundant fructification), which had reached the massive stand stage,

$*$ - $\mathrm{h}=$ height of the maternal stand 
measurements were performed at the base of the canopy (under the canopy), as this level was well differentiated. In all cases (clear cut block sites, with or without installed seedlings) measurements were carried out in a number of points located equidistantly along the characteristic E-W and S-N axes (the four cardinal points being marked with bollards).

Equidistant points, located every two meters, were used for the determination of luminous intensity. During the measurements, the two characteristic axes (E-W and S-N) were materialized through ha string, on which the equidistant points were marked also with a string, but of different colors.

\section{Findings and discussion}

The research findings on the light regime in the versions mentioned above are presented below. As can be seen, in the cut block sites there appeared obvious changes of the light regime, generated by the intensity of the logging operations, the size of the cut block sites and the position of each cut block site sector.

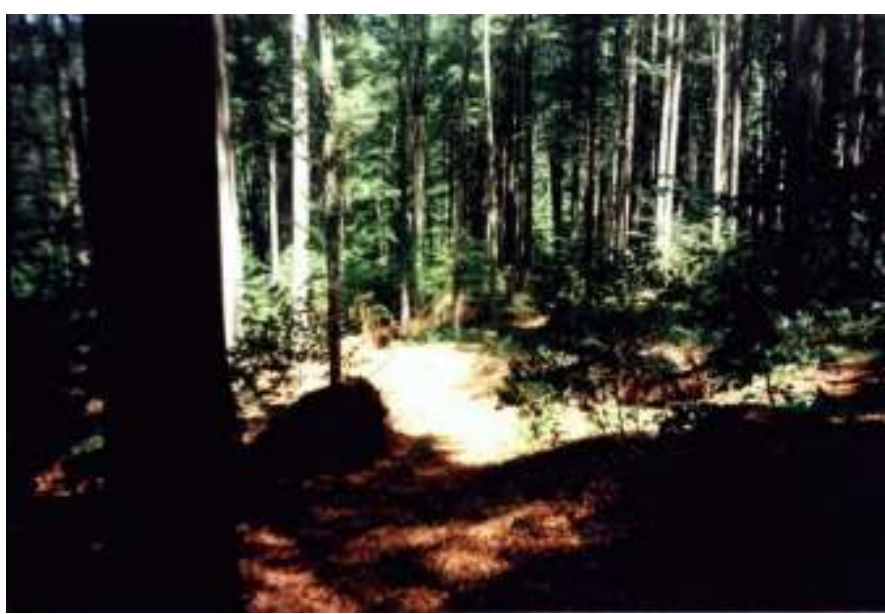

Photo 1. The area of maximum light availability in a clear cut block site (U. P. III u.a. $74 B$ )

Thus, in the clear cut block sites(photo 1), having an elliptical shape of 0.5 $\mathrm{h}^{4} \mathrm{X} 0.75 \mathrm{~h}$, in which the seedlings have not yet been installed, the amount of light that reaches the soil surface, in relation to the open field solar radiation, is 
approx. $1 / 4-1 / 3$ in the eastern and southern sectors, $2 / 3$ in the central sector and, respectively, $2 / 5-1 / 2$ in the western and northern sectors (fig. 1).The area with relatively maximum light availabilityis the central - western one (photo 1), where values of $4 / 5-1 / 1$ of the light from an deforested area are reached (fig. $1)$.

In the case of elliptical cut block sites with installed seedlings (photo 2), measuring $1.0 \mathrm{~h} \times 1.5 \mathrm{~h}$, some variations are found. Thus, the eastern and the southern sectors receive, at the ground surface, approx. 1/5 - 2/5 of the light radiation from an deforested area, the central sector receives slightly over $2 / 3$, while the western and the northern sectors receive $4 / 5-1 / 1$ of the light from an deforested area, which is also the area with relatively maximum light availability.
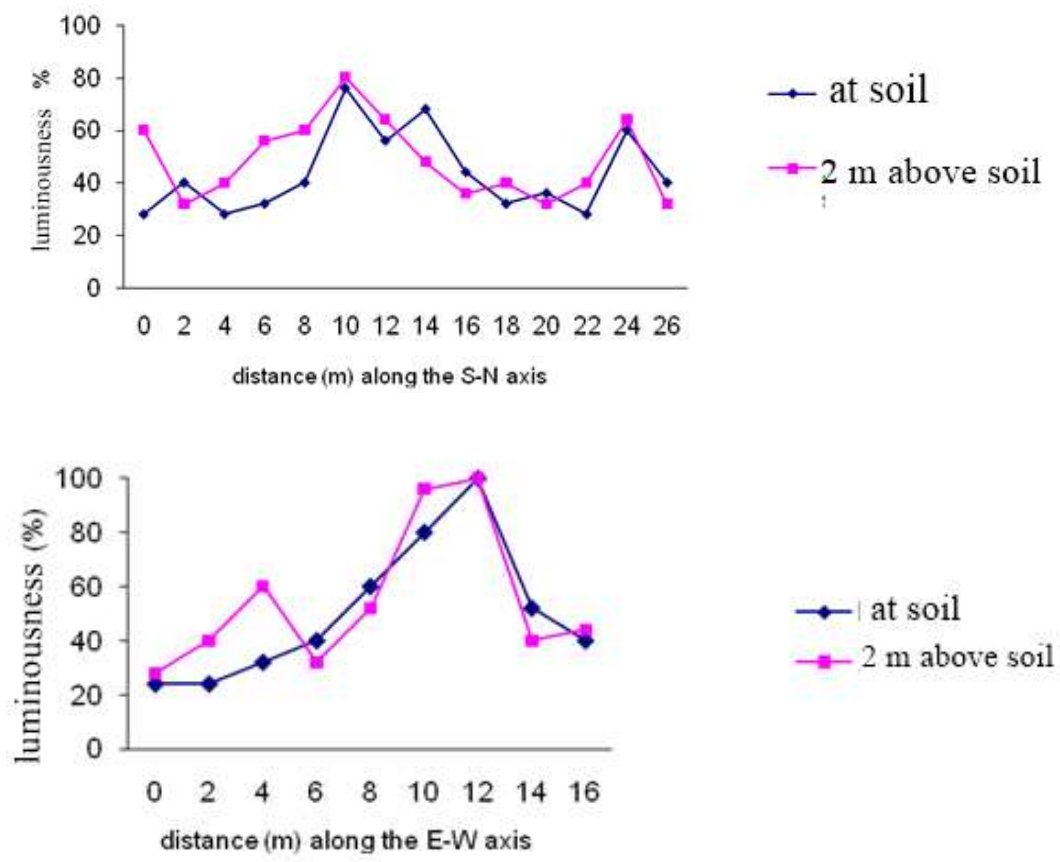

Fig. 1 Variation of light intensity in the clear cut block sites, without installed seedlings $\left(0.5 \mathrm{~h}^{*}, 0.75 \mathrm{~h}\right)$, in a normal beech wood with mull flora (u.a. 74 B, UP III. Sovata Forestry)

Compared to the situations presented above, there appears a series of differences concerning exposure to light, the slope of the surfaces and the intensity of the light in the free atmosphere. 
Thus, in UP I Chiher, in u.a. 66, a surface with $\mathrm{S}-\mathrm{E}$ exposure and $\mathrm{a} 30^{\circ}$ slope in acircular cut block siteof $0.5 \mathrm{~h}$, created by accident, it can be noticed that about $1 / 5$ of full light reaches the soil surface in the southern and western sectors, $4 / 5$ of full light reaches the central sector and about $4 / 5-1 / 1$ of the light from an unforested area reaches the eastern and northern sectors. When the sky is partially covered with clouds and when the intensity of light in the free atmosphere registers variations, the amount of light that reaches the soil surface undergoes changes.

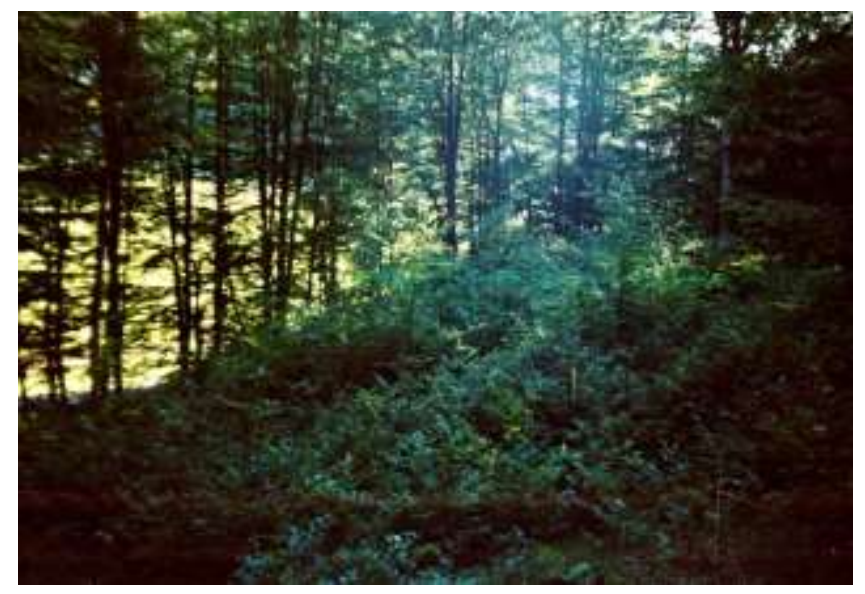

Photo. 2. Elliptical cut block site with installed seedlings (U.P. VI u.a. 127)

Thus in an elliptical cut block site $\left(1.0 \mathrm{~h}^{\square} \times 1.5 \mathrm{~h}\right)$ of UP VI u.a 127, at 1 p.m.,when the sky is overcast, $50 \%$ of full light reaches the eastern sector, $40 \%$ reaches the southern sector, approx. $80-90 \%$ reaches the center of the cut block site, and $75-85 \%$ of the amount of light from an unforested area reaches the western and the northern sectors at soil surface level.

The measurements made in cut block sites with seedlings, emerging after applying progressive fellings in u.a. 127 of UP VI, shows that the light intensity decreases from the tip of the canopy to the ground. The decrease is accentuated in the canopy and much slower in the space underneath the canopy, all the way to the ground. Thus, while an average of $66-67 \%$ is recorded at the level of the canopy ( $2 / 3$ of full light), underneath the canopy it reaches $9 \%$ (under $1 / 10$ of full light) and only $6-7 \%$ of the light from an unforested area is recorded at ground level. In cloudy weather, when the intensity of light in the free

${ }^{\square}$ - the height of the mature stand 
atmosphere is low, approx. $13 \%$ of this light reaches the ground level. Similar values (12-14\%on average) are recorded under the canopy of the seedlings, and light intensity reaches values of $80-90 \%$ above the canopy. Differences are found from one measurement point to another, within the same level, as a result of the foliage structure and the different thickness of the foliage mass located above the measurement point.

\section{Conclusions regarding the light regime in cases where the progressive felling treatment is applied}

1. The amount of light that penetrates into the open cut block sitescreated in the stands varies in relation to the intensity of the felling and the size of the cut block sites.

1. a. Clear cut block sites and, in particular, the large ones (measuring 1.5 $\mathrm{h}$ ), are closer, in terms of the light regime, to open ground areas than to closed forest areas. Cut block sites measuring $-0.5 \mathrm{~h} \times 0.75 \mathrm{~h}-$ receive, on average, $42.8 \%$ of the light from an unforested area. On average, $62 \%$ of the light from an unforested area penetrates cut block sitesmeasuring $1.0 \mathrm{~h} \times 1.5 \mathrm{~h}$.

1. b. The amount of light that penetrates into thinned cut block sites varies much less in relation to the size of cut block sites than in the case of clear cut block sites. This amountmeasures between $19 \%$ and $25 \%$ of the light from an unforested area.

2. There are large differences of light availability between the clear cut block sites. Thus, compared with the average, the eastern sector receives $77.1 \%$, the southern sector $-58,4 \%$, the central sector $-106.2 \%$. The other two western and northern - sectors get light amounts of $111.8 \%$ and, respectively, $139.8 \%$ compared to the average.

The area with relatively maximum light availabilityis the central-northwestern one. In the case of thinned cut block sites, the differences of light availability between cut block site sectors are smaller than in the case of clear cut block sites, but they display the same features.

3.We may notice a series of differences in relation to exposure to light, the slope of the surfaces and the intensity of the light in the free atmosphere. For example, when the sky is overcast, the eastern sector receives $78.5 \%$ compared to the average, and the southern sector $-62.8 \%$. The central sector becomes the sector with relatively maximum light availability $-133.4 \%$. The other two sectors, western and northern,receive approximately equal amounts of light, $111.8 \%$ and, respectively, $139.8 \%$ compared to the average.

4.The vertical distribution of light intensity in cut block sites with installed seedlings shows that brightness decreases from the tip of the canopy to the 
ground. The decrease is accentuated in the canopy and much slower in the space underneath the canopy, all the way to the ground. Thus, if we take the average value at the level of the canopy, $66-67 \%$ of full light, this value reaches $9 \%$ under the canopy, and just $6-7 \%$ of the light from an unforested area at ground level.

5.When the weather is cloudy and when the intensity of light in the free atmosphere is low, there is a sharp decrease in the canopy, from $80-90 \%$ above it to approx. $13 \%$ underneath it. In the space underneath the canopy, all the way to the ground level, the intensity of light is practically constant, amounting to $13 \%$.

\section{References}

Berbecel, O., ş. a., 1971: Agrometeorologie. Editura Ceres, Bucureşti.

Bodnariuc, N., Vădineanu, A., 1982: Ecologie generală. Editura Didactică şi pedagogică, Bucureşti.

Brega, P., 1992: Problematica regenerării amestecurilor de răşinoase şi fag. Revista Pădurilor, no. 1.

Chiriţă, C., D., 1974: Ecopedologia. Editura Academiei R. S. R.

Chiriță, C., D., ş. a., 1977: Staţiuni forestiere. Editura Academiei R. S. R.

Chiriţă, C., D., Doniţă, N., Ivănescu, D., Lupe, I., Milescu, I., Stănescu, V., Vlad, I. ș. a., 1981: Pădurile României. Editura Academiei Republicii Socialiste România, București.

Ciobanu, P., Bândiu, C., Vlonga, St., 1988: Contribuţii la cunoaşterea regimului ecologic şi punctelor de regenerare circulare în brădeto-făgete. Sesiunea de comunicări ştiinţifice a Facultăţii de Silvicultură şi Exploatări Forestiere din Braşov.

Constantinescu, N., 1963 (1973): Regenerarea arboretelor. Editura Agro-silvică. Bucureşti (Editura Ceres Bucureşti).

Covrig, I., 2000: Efectul microclimatic al unor lucrări silvotehnice asupra regenerării fagului. A IV-a Sesiune ŞStiințifică, Ecologia şi protecţia ecosistemelor, Universitatea Bacău - Secţia Biologie.

Covrig I, 2013, Regenerarea fagului, Editura Bioflux Cluj-Napoca, ISBN 978-6068191-59-1

Doniţă, N., Ceianu, I., Purcelean, Şt., Beldie, Al., 1977: Ecologie forestieră. Editura Ceres. Bucureşti.

Hanganu, C., 1963: Referitor la regenerarea făgetelor. Revista Pădurilor, no. 1.

Marcu, M., 1962: Cercetări asupra posibilităţilor de producere a îngheţurilor târzii şi timpurii, în scopul prevenirii efectului dăunător al acestora asupra culturilor forestiere. Lucrare ştiințifică I. P. Braşov, vol. V.

Marcu, M., 1970: Cercetări privind regenerarea naturală în făgete, pădurea WartheBraşov. Buletin I. P. Braşov., vol. XII.

Milescu, I., Alexe, A., 1967: Fagul. Editura Agro-Silvică, București. 
Săvulescu, Al., Negruţiu, A., Creţianu, I., Văcaru, Gh., 1967: Cercetări privind regenerarea pe cale naturală a fagului în urma aplicării tăierilor rase în benzi la DREF Braşov. Buletinul Institutului Politehnic Braşov, seria B, vol. IX.

Teissier du Cros, E., ş. a., 1981: Le hetre. Institut National de la Recherche Agronomique, Departement des Recherches Forestieres.

****, 1996: La gestion durable des forets: contribution de la recherche. Institut National de la Recherche Agronomique, no. 12

Vlonga, St., Fărcaş Cecilia, 1990: Cercetări privind lumina de care dispune seminţişul natural în făgetele montane parcurse cu prima tăiere succesivă, progresivă şi de transformare la grădinărit. Revista Pădurilor, nr. 3-4. 